\title{
English for Specific Purposes: Brief History and Definitions
}

\author{
Carolina González Ramírez \\ Escuela de Lenguas Modernas \\ Universidad de Costa Rica
}

\begin{abstract}
English for Specific Purposes was born in the 1960s as a technical texts-analysis area. The study of language use over language form strengthened at the end of the decade and materials development became a popular trend. The 1970s and 1980s witnessed the consolidation of the movement in the emphasis on language skills and booming research. Central concepts such as genre, rhetorical moves and expert consultant were introduced. Research has boomed in the last 20 years, specially in the international context, where new journals and vast submission of papers have shown the increased importance of ESP. The evolution ESP and its definitions have developed hand by hand. Seen as an approach by some and a discipline by others and displaying changing characteristics of variables, ESP has and will always shape itself to meet learners' specific professional or vocational language needs and thus possesses immediate relevance and validity, for as stated by Harding (2007), ESP teaches "the language for getting things done" (p. 6).
\end{abstract}

Key words: ESP, history of ESP, ESP definitions, ESP development, learners' needs

\section{Resumen}

Inglés con Fines Específicos (o ESP por sus siglas en inglés) nació en la década de 1960 como un área dedicada al análisis de textos técnicos. El énfasis en el uso del lenguaje en lugar de su forma se fortaleció a finales de la década, al igual que la tendencia de desarrollo de materiales. Las décadas de 1970 y 1980 vieron la consolidación del movimiento a partir del énfasis en las destrezas del lenguaje y el gran aumento en investigación. Se introdujeron conceptos claves tales como género, movimientos retóricos y asesor especialista. La investigación en el área ha prosperado en los últimos 20 años, especialmente en el ámbito internacional, donde nuevas revistas especializadas y la gran cantidad de artículos presentados para publicación comprueban la actual relevancia del área. Así como ha evolucionado el campo de ESP, así también han cambiado las definiciones dadas a este. Ya sea que ESP se considere una estrategia o una disciplina, o que cambien sus características o variables, ESP siempre se ha adaptado y continuará adaptándose para satisfacer las necesidades vocacionales o profesionales de su población meta, por lo que siempre tendrá un valor añadido de inmediatez y actualidad, pues como lo indica Harding (2007), ESP enseña el lenguaje para llevar a cabo ("the language for getting things done" (p. 6).

Palabras claves: historia de ESP, definiciones de ESP, evolución de ESP, necesidades del estudiante de ESP 


\section{English for Specific Purposes: Brief History and Definitions}

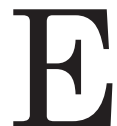
nglish for Specific Purposes (ESP) has become a fruitful field over the last three decades. As a learner-centered approach, its main purpose has been that of fulfilling the specific needs of target learners to satisfy either their professional or vocational demands. But how did it come to this aim? What is the history of ESP both as a theory and research field? By learning how the origins of ESP have responded to society's needs and history, a wider perspective on its past and current relevance might be gained, which can lead us to better understand the current trends and concepts of the field.

The first part of this review of the literature intends to give an overview of the origins and history of ESP by looking at its development and characteristics in each decade since its beginning in the 1960s. Occasionally, decades overlap, for changes do not happen in isolation but usually conflate and interact.

The second half of this paper addresses the main definitions that have been given of ESP while emphasizing those of the most relevant practitioners and researchers in the field. The movement's main features are highlighted and explained when appropriate, since it seems that a comprehensive definition of ESP cannot be detached from at least mentioning some of its key characteristics and elements.

\section{History}

Hutchinson and Waters (1987) traced the early origins of English for
Specific Purposes (ESP) to the end of Second World War. In the new commerce-driven world, many saw the need of learning English, which was considered the accepted international language. Nonnative speakers saw it as the new lingua franca that responded to their needs of cross cultural communication, business doing, and information sharing (Teodorescu, 2010).

During the 1960's, changes in the world's markets resulted in the rising of ESP as a discipline. According to Hutchinson and Waters (1987), ESP emerged due to the development of the world's economy, which entailed the progress of technology, the economic power of oil-rich countries, and the increasing amount of overseas students in English-speaking countries (pp. 6-7). Also, according to Johns and DudleyEvans (1991), the international community recognized the importance of learning English not only as a means to achieve the transmission of knowledge and communication but also as a neutral language to be used in international communication (pp. 301-302).

The first boost of ESP came from the register analysis of scientific and technical writing. Logically, the movement gave special importance to semi- or subtechnical vocabulary. Smoak (2003) describes the instructors' believed job as "to teach the technical vocabulary of a given field or profession" (p. 23). While this detailed study of language in specific registers demonstrated a very positive, early interest in functional lexis, it showed an extreme concentration on form and offered little explanation about why and how the sentences were formed and combined as they were.

Rhetorical and discourse analysis attempted to answer these questions 
and in doing so, as Dudley-Evans (2001) commented, "introduced the idea of relating language form to language use, making use the main criterion for the selection of ESP teaching materials" (p. 22). This new movement in ESP prioritized the rhetorical functions of language over its form since, as Maleki (2008) clearly explained, discourse analysis "focused on the communicative values of discourse rather than the lexical and grammatical properties of register" (ESP Background, para. 4) and reinforced the area's emphasis on research and analysis of texts. In this regard, Johns (2013) described through a series of sample research papers the shift of emphasis of ESP during this period, going from statistical grammar accounts to a deeper interest in the relation between grammar and rhetoric. However, the discourse analysis of ESP was primarily concerned with language and gave no attention to the development of study skills. This, then, became the focus of EAP during the late 1970's.

Skill-based courses at the end of the 70 s intended to address the learners' specific foreign language needs; to do so, needs analyses had to be carried out. The movement believed that teaching how language works was not enough; the language-learning processes involved should be addressed as well so that learners would transfer these study skills to their real life tasks. Consequently, the learners' purpose for learning the target language became of utmost importance and so did needs analyses (Maleki, 2008).

The decades of 1970's and 1980's saw the consolidation of the ESP movement. Numerous articles on the field were published, such as Munby's mod- el for needs analysis and Hutchinson and Waters' influential papers. The latter two authors questioned many ESP long-held ideas and believed that ESP students should be led towards developing the "underlying competence" (1987, p. 70$)$ to eventually become independent learners. Closely related to this concept, Hutchinson and Waters outlined the concept of learnercentered approach, which focuses on the process of learning, emphasizes the exploitation of the learner's already possessed skills (acquired at work or through academic study), and takes into account students' different learning styles (Dudley-Evans \& St. John, 1987, pp. 25-26).

The decades of the $70 \mathrm{~s}$ and $80 \mathrm{~s}$ were also witness to controversy in ESP. The analysis of ESP resulted in two main views: that of "the wideangle approach," which advocated for the teaching of English through topics beyond students' specialist areas, and the "narrow-approach," which claimed that the focus of the language studies should be on the students' specific area of development. Another debate of the $70 \mathrm{~s}$ and $80 \mathrm{~s}$ what that of skill specificity. Some research studies proved monoskill emphasis useful, specially in regard to reading, but the ESP community considered that such "concentration on one skill is limiting" (Johns \& Dudley-Evans,1991, p. 305) and that working on several skills simultaneously would actually enhance the language learning processes. Johns and Dudley-Evans (1991) also pinpointed that in "the late 1970s and 1980 s, theoretical work seemed to lag behind materials development" (p. 303), which became a new trend of ESP work and research at the time. 
Finally, instructor's specialization was an issue of concern as well. According to Johns (2013), a study carried out by Tarone et al in 1981 not only maintained the rhetorical-grammar relationship but also introduced the concept of using the area specialist as a contentexpert consultant. From that moment on, "subject-specialist informants" (p. 8) were more commonly involved as part of ESP research. Content and skill specificity, material design, and the instructor as an expert were topics of debate during the 70 s and 80 s.

Another important contribution to ESP during the $80 \mathrm{~s}$, in the view of Johns, was the introduction of two key ESP terms: genre analysis and rhetorical moves, which continue to be subject of intense research work in ESP (pp. 11-12).

Genre analysis was and continues to be a flourishing area of study. Paltridge (2013) affirms that today's definition of genre is based on Swales': "a class of communicative events with some shared set of communicative purposes" (p. 347). Delimiting what a discourse community's genre is "establish[es] the constraints on what is generally acceptable in terms of how the text should be written or spoken, what issues it will address, and how it can do this" (Paltridge, 2013, p. 347). Identifying an aimed genre may help ESP students reproduce it and participate in it successfully by imitating conventions and limitations of the text. There might be genres, however, that vary in their linguistic and rhetorical features, but all of them should have a communicative purpose. Such a purpose may change over time and can even vary across cultures - a concept referred to as "genre volatility" by
Johns (2013, p. 11). Genres may also be related and based on other genres, a complex relationship that continues to enrich ESP genre analysis.

The concept of rhetorical moves is also highly salient in ESP. The moves contribute to constituting a genre and serve a communicative purpose subordinate to the overall communicative purpose of the text. In traditional genre analysis, a text's moves or "functional components" (Connor, 2000, p. 2) are used for some identifiable rhetorical purpose that is clearly different from other parts of the text. Such differentiation is observable in the text's division into meaningful units through the use of subtitles, sections, key words, and transitions, among others. Connor (2000) states that although moves can vary in size, they "all contain at least one proposition” (p. 6) based on both the general rhetorical objectives of the text and the community's agreements on the form of a text. In the analysis of rhetorical moves, indicators of both the text function and its boundaries and divisions are necessary.

During the last twenty years the ESP field has increased dramatically. Hewings (2002), co-editor of the journal English for Specific Purposes, analyzed the issues of this journal for the last twenty years and came up with some interesting conclusions in his article "A History of ESP Through 'English for Specific Purposes." First, the increased number of studies conducted outside the U.S. and U.K., such as Central and South America, China and Hong Kong, demonstrates the growing acceptance of ESP as an academic discipline - a conclusion also drawn by Johns and explained below. A second interesting conclusion explained in his 
article is the specificity towards which ESP, which includes EAP and EOP, is headed. Thirdly, the topics observed seem to have become more EOP oriented and apparently, they have obviated more general program descriptions. The current trend, according to Hewings, is text or discourse analysis. This tendency proves, as he mentioned, the "growing realisation that to provide convincing and effective ESP courses or material, we need to know a considerable amount about target situations" (Topics of papers, para. 7). Teaching ESP means, therefore, a deeper knowledge of the context and the texts that occur within it.

The decades of the 1990s and 2000s have seen a rapid increase in research and have continued the expansion on major ESP topics. According to Johns (2013), the emergence of international journals as well as the marked rise in the amount of international submissions and publications have consolidated the importance and relevance of ESP today. Moreover, the new emphases given to already established concepts, such as international rhetorics and learner genre awareness, as well as the more profound and continuous research on corpus studies, demonstrate the steady evolution of research in the ESP arena.

ESP has existed as a separate branch of language teaching for around 40 years. At the beginning, it focused upon the specific lexicon of technical and scientific texts, but it soon changed its emphasis towards the rhetorical uses of language in precise discourses. Next, the four skills, which were neglected by all previous methods, were assessed and addressed through the introduction of needs analysis studies.
Finally, Hutchinson and Waters (1987) polished the concept of ESP and established the importance of teaching students the skills and language that they need to achieve their desired language performance.

It has certainly been a changing but fruitful road for ESP, and even if some say that the evolution of this area of language study has responded mainly to teaching procedures and materials development, its principles and theory have been more clearly outlined and shaped by the passing of time.

\section{Definitions of ESP}

Dudley-Evans and St John (1998) address three of the most widely-recognized definitions in the field in their book Developments in ESP: A Multidisciplinary Approach. The first is the one provided by Hutchinson and Waters (1987), who viewed ESP as an approach, not a product, meaning that it "does not involve a particular kind of language, teaching material, or methodology" (p. 2). This might be considered the most general of the definitions. Dudley-Evans (2001) also cited Strevens' definition, which aims at defining ESP by distinguishing both its absolute and variable characteristics. Among some of the absolute features, he mentioned ESP's relationship with other disciplinary areas and occupations by using their methodologies and activities, its focus on and analysis of the language related to a particular area, and its contrast to General English. Anthony (1997) stated that, during Japan's Conference on ESP, Dudley-Evans included another feature within this definition, that "ESP 
is defined to meet specific needs of the learners" (p. 2). In addition, the two variable characteristics are its restriction in terms of skills to be learned and the lack of a pre-established methodology. Moreover, Dudley-Evans (2001) briefly explained Robinson's view of ESP as a goal-directed approach that has a limited time period and is aimed at adults in homogeneous learning environments. According to Anthony (1997), Dudley-Evans also stated that ESP is usually aimed at professionals or tertiary-level students with some target language basic knowledge but is not limited to these populations exclusively. All these absolute and variable features emphasize the purposeful nature of ESP as an approach that shapes itself according to the learner's needs.

In spite of recognizing the strengths of these definitions, Dudley-Evans and St John (1998) insisted on the idea that ESP should be defined neither as a subject-content directed discipline nor as a distinct area from General English. They considered ESP a discipline that attempts to meet the needs of a specific population of students, employs methodologies and materials from the discipline it is centered on, and focuses on the language and discourse related to it. Dudley-Evans (2001) also included three variables: ESP has to be related to specific disciplines, use a different methodology from the one used in General English, and be aimed at intermediate to advanced adult learners (p. 131). Such definition resembles the one provided by Strevens, which migh be ranked as the most comprehensible one, yet Dudley-Evans and St John modified it by omitting variables such as the one contrasting ESP to General English, and including others such as whom ESP is aimed at. In the words of Smoak (2003), "ESP is English instruction based on actual and immediate needs of learners. ESP is needs based and task oriented" (p. 27).

Finally, Gatehouse (2001) addressed the very name of the field in her paper "Key Issues in English for Specific Purposes (ESP) Curriculum Development," where she discussed the meaning of the word "specific" and clarified that it addresses the specificity of the purpose or aim of this teaching area, not the special registers or vocabulary entailed (The Meaning of the Word 'Special' in ESP, para. 3).

All the previous definitions and statements have contributed, at some point or another through the history of the field, to better delimit the scope and aim of ESP. They have all built ESP's niche within foreign language teaching and they have all emphasized that "in ESP . . . the purpose for learning is paramount and related directly to what the learner needs to do in their vocation or job" (Harding, 2007, p. 6). ESP was born and will continue to address the learners' needs and purpose to learn a language that will most likely help them to communicate in a globalized world where the sense of immediacy of need can best be fulfilled by English for Specific Purposes instruction.

\section{Conclusion}

The early beginnings of English for Specific Purposes (ESP) in the 1960s emphasized the grammatical analysis of technical texts. By the end of the decade, discourse analysis gained relevance and in the $1970 \mathrm{~s}$, emphasis on students' necessary skills resulted 
in the development of needs analyses. During the 1980s, the learner-centered approach gathered strength and materials development productions attempted to respond to this new trend. The last twenty years have seen the spur of ESP as a vast theoretical and research ground.

The definitions of ESP have also evolved; each of them has evidenced the changes in theoreticians', researchers', and practitioners' views. However, all the definitions given have had common elements, sometimes referred to as "absolute features", that embrace ESP's aim at meeting the very specific needs of a very specific group of learners.

With this in mind and taking into account that change is a constant in our globalized world, ESP will continue to build on its history by tracing its path in the years to come.

\section{Bibliography}

Anthony, L. (1997). Defining English for specific purposes and the role of the ESP practitioner. Center for Language Research 1997 Annual Review, pp. 115-120. Retrieved September 21, 2013, from www. antlab.sci.waseda.ac.jp/abstracts/ Aizukiyo97.pdf

Connor, U. (2000). Variation in rhetorical moves in grant proposals of US humanists and scientists. TextInterdisciplinary Journal for the Study of Discourse, 20(1), 1-28.

Dudley-Evans, T. (2001). English for specific purposes. In R. Carter \& D. Nunan (Eds.). Teaching English to speakers of other languages (131136). Cambridge: Cambridge University Press.
Dudley-Evans, T., \& St John, M. (1998). Developments in English for specific purposes: A multi-disciplinary approach. Cambridge: Cambridge University Press.

Gatehouse, K. (2001). Key issues in English for specific purposes. The Internet TESL Journal. Retrieved August 9, 2008 from http://iteslj. org/Articles/Gatehouse-ESP.html

Harding, K. (2007). English for specific purposes: Resource Books for Teachers. Oxford: Oxford University Press.

Hewings, M. (2002). A history of ESP through 'English for specific purposes'. ESP-World, 1(3). Retrieved September 21, 2013, from http:// www.esp-world.info/Articles_3/issue_3.html

Hutchinson, T., \& Waters, A. (1987). English for specific purposes: A learning-centred approach. Cambridge: Cambridge University Press.

Johns, A. (2013). The history of English for specific purposes research. In B. Paltridge \& S. Starfield (Eds.), The handbook of English for specific purposes (pp. 5-30). Oxford: WileyBlackwell.

Johns, A., \& Dudley-Evans, T. (1991). English for specific purposes: International in scope, specific in purpose. TESOL Quarterly, 25(2), 297314. Retrieved from http://www. jstor.org/stable/3587465

Maleki, A. (2008). ESP Teaching: A Matter of Controversy. ESP-World, 7 (17). Retrieved September 21, 2013, from http://www.esp-world. info/Articles_17/issue_17.htm

Paltridge, B. (2013). The history of English for specific purposes research. In B. Paltridge \& S. Starfield (Eds.), The handbook of English for specific purposes (pp. 347-366). 
Smoak, R. (2003). What is English for Teodorescu, A. (2010). Teaching Engspecific purposes? English Teaching Forum Online, 41(2), pp. 22-27. Retrieved October 6, 2013, from http://americanenglish.state.gov/ lish for Specific Purposes. Petroleum - Gas University Of Ploiesti Bulletin, Philology Series, 62(2), 67-74.

files/ae/resource_files/03-41-2-g.pdf 